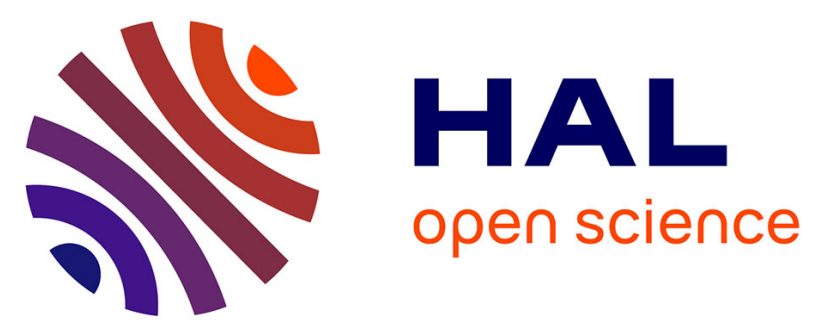

\title{
Performance evaluation of indirect evaporative cooling using whole-building hygrothermal simulations
}

\author{
Marijke Steeman, Arnold Janssens, Michel De Paepe
}

\section{To cite this version:}

Marijke Steeman, Arnold Janssens, Michel De Paepe. Performance evaluation of indirect evaporative cooling using whole-building hygrothermal simulations. Applied Thermal Engineering, 2009, 29 (1415), pp.2870. 10.1016/j.applthermaleng.2009.02.004 . hal-00556849

\section{HAL Id: hal-00556849 \\ https://hal.science/hal-00556849}

Submitted on 18 Jan 2011

HAL is a multi-disciplinary open access archive for the deposit and dissemination of scientific research documents, whether they are published or not. The documents may come from teaching and research institutions in France or abroad, or from public or private research centers.
L'archive ouverte pluridisciplinaire HAL, est destinée au dépôt et à la diffusion de documents scientifiques de niveau recherche, publiés ou non, émanant des établissements d'enseignement et de recherche français ou étrangers, des laboratoires publics ou privés. 


\section{Accepted Manuscript}

Performance evaluation of indirect evaporative cooling using whole-building hygrothermal simulations

Marijke Steeman, Arnold Janssens, Michel De Paepe

PII:

S1359-4311(09)00056-8

DOI:

10.1016/j.applthermaleng.2009.02.004

Reference:

ATE 2738

To appear in:

Applied Thermal Engineering

\section{APPLIED \\ THERMAL \\ ENGINEERING}

17 July 2008

Received Date:

5 January 2009

Revised Date:

8 February 2009

Please cite this article as: M. Steeman, A. Janssens, M.D. Paepe, Performance evaluation of indirect evaporative cooling using whole-building hygrothermal simulations, Applied Thermal Engineering (2009), doi: 10.1016/ j.applthermaleng.2009.02.004

This is a PDF file of an unedited manuscript that has been accepted for publication. As a service to our customers we are providing this early version of the manuscript. The manuscript will undergo copyediting, typesetting, and review of the resulting proof before it is published in its final form. Please note that during the production process errors may be discovered which could affect the content, and all legal disclaimers that apply to the journal pertain. 


\title{
Performance evaluation of indirect evaporative cooling using whole-building hygrothermal simulations
}

\author{
Marijke Steeman* \\ Ghent University, Department of Architecture \& Urban Planning, \\ Jozef Plateaustraat 22, B-9000 Gent, Belgium \\ Tel +3292643752 / Fax +3292644185 / Email: Marijke.Steeman@UGent.be \\ ${ }^{*}$ Corresponding author

\section{Arnold Janssens} \\ Ghent University, Department of Architecture \& Urban Planning, \\ Jozef Plateaustraat 22, B-9000 Gent, Belgium

\section{Michel De Paepe} \\ Ghent University, Department of Flow, Heat and Combustion Mechanics, \\ Sint - Pietersnieuwstraat 41, B-9000 Gent, Belgium
}

\section{Abstract}

In an indirect evaporative cooling (IEC) installation the return air is cooled by adiabatic humidification. In an air/air heat exchanger this air cools down the supply air. This paper presents a simulation methodology focusing on the interaction between the thermal performance of an IEC system and the heat and moisture balance of the building where it is applied. The thermal effectiveness of an IEC system is first studied by measurements. It was found that the 
effectiveness is independent of the air inlet conditions. In the second part the influence of the ventilation rate, the indoor moisture production and the moisture buffering capacity on the thermal performance were evaluated using dynamic calculations with the multizone building simulation program TRNSYS. Increasing the indoor moisture production and lowering the ventilation rate both reduce the thermal performance of the system. Hygroscopic materials may ameliorate the applicability of IEC.

\section{Keywords}

Indirect evaporative cooling, indoor humidity, thermal performance, effectiveness, dynamic simulations

\section{Introduction}

During the last decades, the need for cooling of buildings has increased. A $30 \%$ rise in worldwide sold air conditioners is noted from 2000 to 2004 and is expected to increase to $63 \%$ till 2008 [1]. The main drawback of these systems is their large energy use and their contribution to the emission of greenhouse gases. Contrary to air conditioning, passive cooling techniques may provide cooling with more limited environmental impact. However, the indoor temperature and humidity are free floating when applying passive cooling techniques, which limits their applicability.

Evaporative cooling is a passive technique in which the dry bulb temperature of air is lowered by evaporation of water. Two types of evaporative cooling systems can be distinguished. In a direct evaporative cooling installation (DEC) the supply air to the building is humidified. In an indirect evaporative cooling system (IEC) a secondary air flow is cooled by adiabatic humidification using sprayed water. In an air to air heat exchanger this air cools down the supply air to the building. Fresh outdoor air or building return air can be used as secondary air. The advantage of indirect 
evaporative cooling is that in contrast to direct evaporative cooling, the vapour content of the supply air is not increased. This will lead to a more comfortable indoor climate and fewer moisture problems in the indoor environment are expected.

Indirect evaporative cooling performs best in dry hot areas but also has good potential in most locations in Europe because of the moderate humidity during summer. [2] investigates the potential of direct and indirect evaporative cooling for different types of climates. An evaluation procedure is presented which shows that the cooling demand can often be satisfied completely combining direct and indirect evaporative cooling.

When return air is used as secondary air, water is evaporated and heat is withdrawn from the air due to latent heat transfer. As a result the return air is cooled. At the same time the supply air is cooled indirectly by sensible heat transport through the heat exchanger walls. The wet bulb temperature of the return air is a measure for the maximum vapour content of the return air at adiabatic saturation, which corresponds to the lowest possible temperature to which the return air may theoretically be cooled. The IEC-effectiveness $\varepsilon$ can be defined by the ratio of the actual temperature reduction in the supply air realized by an IEC system to the maximum possible temperature change, which is given by the temperature difference between the dry bulb of the outdoor air and the wet bulb of the return air entering the heat exchanger [3], see Eq. 1:

IEC-effectiveness: $\varepsilon=\frac{\theta_{s, 1}-\theta_{s, 2}}{\theta_{s, 1}-\theta_{r, w b, 1}}(1)$

The IEC-effectiveness is mainly characterized by the heat transfer surface, the air flow rate through the heat exchanger and ratio between the supply and return air flow rate. Depending on the geometry of the heat exchanger and the primary and secondary mass flow rates the effectiveness may range from 40 to $80 \%$ according to ASHRAE [3]. 
The aim of this paper is to clarify the interaction between the indoor humidity and the thermal performance of an indirect evaporative cooling system where the return air is used as secondary air. A recent international research project in the framework of the International Energy Agency (IEA/ECBCS) entitled "Whole Building Heat, Air and Moisture response (MOIST-ENG) was started in 2003 and dealt with the need to develop improved models to evaluate the integral performance of the whole building, considering the presence of moisture within porous elements [4-6]. In the frame of this international project several researchers focused on the interaction between HVAC systems and the indoor moisture balance, which may be significant especially in buildings with high hygroscopic contents e.g. museums and libraries. Despite of the importance of taking into account moisture buffering in the evaluation of HVAC systems, only few publications were found in literature: Catalina et al. [7] noted that neglecting the moisture buffering capacity of the indoor environment penalises the evaluation of radiant cooling panels. The authors showed that hygroscopic materials decrease the risk of condensation on the surface of the ceiling and improve the overall performance of the system. Maalouf et al. [8] looked at the effect of taking into account coupled heat and moisture transport through the building envelope on the performance and operation of a desiccant cooling system. Variations in the COP of the system up to $6 \%$ were noted between a model taking into account the humidity transport in the walls and one neglecting it. Recently, Woloszyn et al. [9] studied the effect of combining a relative-humidity-sensitive ventilation (RHS) system with indoor moisture buffering materials. By means of Heat, Air and Moisture transfer models the performance of different strategies was analysed in terms of indoor air quality and energy efficiency. The results demonstrated that RHS-ventilation is able to reduce the building energy demand and confirmed that hygroscopic materials are able to damp the humidity variations in the indoor climate. In a recent study Barbosa and Mendes performed a combined simulation of a HVAC system with a whole building hygrothermal model [10]. In the simulated case study, disregarding moisture may lead to 
oversizing the HVAC system by $13 \%$ and underestimating the cooling energy consumption by 4\%. Osayintola et al. estimated the effect of hygroscopic materials on the energy consumption in buildings [11]. They showed the possibility to reduce the heating and cooling energy consumption respectively up to $5 \%$ and $30 \%$ when applying hygroscopic materials combined with a well-controlled HVAC-system.

So far no research was found on the interaction between the thermal performance of an indirect evaporative cooling system and the building moisture balance. In this paper first an integrated simulation approach is given. The necessary parameters to the model are defined by means of measurements. Next, the potential of IEC-systems to improve the thermal comfort in a typical application in Belgium is investigated using dynamic simulations with TRNSYS [12].

\section{Simulation methodology}

\subsection{Coupling approach}

As the performance of the installation depends on wet bulb temperature of the return air, the indoor temperature obtained using IEC is defined both by the room heat and moisture balance. Typically the moisture balance includes convective vapour transfer by infiltration and ventilation

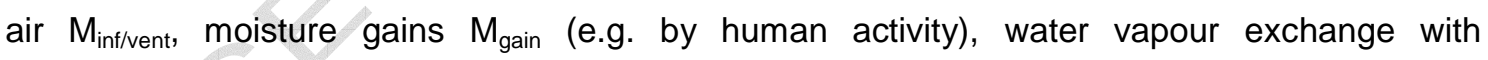
hygroscopic materials $M_{\text {buff, }}$ moisture gains or removals due to humidifying or dehumidifying systems $M_{\text {de/hum }}$ and convective vapour transfer between zones $M_{\text {coupl }}(E q .2)$.

$$
M_{\mathrm{inf}}+\sum_{k} M_{\text {vent }, k}+M_{\text {gain }}+M_{\text {buff }}+M_{\text {hum }}-M_{\text {dehum }}+\sum_{k} M_{\text {coupl }, k}=V \frac{d \rho_{v}}{d t}(2)
$$

Due to the uncertainty of many parameters related to moisture buffering water vapour exchange with porous materials is often difficult to assess. As a result building energy simulation (BES) programs such as TRNSYS use simplified models to predict the relative humidity [13]. In this approach a lumped model is used in which the moisture capacity of walls, furniture and room air 
are combined into one single room moisture capacity. [12]. The effective capacitance $C$ is calculated using Eq.3 and 4 taking into account the available buffering surface, the material properties and the calculated penetration depth $\Delta$ of the porous material. A detailed derivation of the equations is reported in [13]. In the following simulations, the moisture balance can be reduced from Eq.2 to 5, and is used to define the room vapour pressure at every timestep of the calculation.

$$
\begin{aligned}
& C=1+\left(\frac{R_{v} T}{V} \sum S \cdot \frac{\Delta \cdot \rho \xi}{p_{v, \text { sat }}\left(\theta_{i}\right)}\right) \\
& \Delta=\sqrt{\left(\frac{\delta_{v} \cdot t \cdot p_{v, \text { sat }}\left(\theta_{i}\right)}{\rho \xi \cdot \pi}\right)}(4) \\
& M_{\mathrm{inf}}+\sum_{k} M_{v e n t, k}+M_{\text {gain }}=C \frac{d p_{v}}{d t} \frac{V}{R_{v} T}
\end{aligned}
$$

The approach used in this paper has the advantage to be able to evaluate the performance of indirect evaporative cooling without the need of numerical models at component level, i.e. describing the wet surface heat exchanger numerically, which may require a large calculation time. The room temperature follows from the heat flow balance of internal and solar gains, infiltration and transmission heat gains or losses, and the convective heat removed by the IEC coupled ventilation system. This latter term couples the heat flow balance to the moisture balance through the definition of IEC-effectiveness (Eq.1). In order to assess the indoor conditions in a room with an IEC-system by means of BES-models, in every timestep the supply air temperature is calculated using Eq.1 assuming a constant IEC-effectiveness (Fig.1). The correctness of this assumption will be first studied by means of measurements.

\subsection{IEC-effectiveness}

In order to determine the thermal effectiveness of the technique, measurements were carried out in an air handling unit (AHU) containing an indirect evaporative cooling installation [14]. The 
evaporative cooling system consists of a double cross flow heat exchanger in polypropylene (Fig.2). Nozzles located upstream of the heat exchanger are wetting the return air in the first part of the heat exchanger. The water is collected in the sump below the heat exchanger and recirculated. Every five minutes temperature and relative humidity in the supply and return air before and behind the heat exchanger were measured [15].

In fig. 3 the difference between the dry bulb temperature of the supply air and the wet bulb temperature of the return air is plotted on the x-axis, the temperature drop in the supply air obtained using IEC is shown on the y-axis. According to Eq.1, the IEC-effectiveness is given by the slope of the plotted data and could be derived by means of linear regression. The measurements show that the performance of an IEC system is independent of the inlet conditions of temperature and relative humidity of both outdoor air and return air. Measured values of the IEC-effectiveness from different installations are given in table1. Note that these values are substantially higher than the values mentioned in the introduction which is caused by the specific design of the double heat exchanger.

\subsection{Control strategy}

A good control strategy is essential to make the technique perform well. Therefore the control criteria should be carefully chosen to ensure that the evaporative cooling is working properly as long as a cooling demand is present, and no heating of the supply air is occurring e.g. during colder days. Therefore the different stages in which the AHU may operate are included in the simulation model:

A. During occupancy hours
a. $\theta_{i}<\theta_{i, s e t}: \quad \dot{V}=\dot{V}_{\min }$
b. $\theta_{i}>\theta_{i, s e t}: \quad \dot{V}=\dot{V}_{\max }$
i. $\theta_{e}>18^{\circ} \mathrm{C}$ and $\theta_{e}-\theta_{i, w b}>2^{\circ} \mathrm{C}: \theta_{s, 2}=\theta_{s, 1}+\varepsilon\left(\theta_{s, 1}-\theta_{i, w b}\right)$ (IEC) 


\section{ii. $\theta_{e}<18^{\circ} \mathrm{C}$ or $\theta_{e}-\theta_{i, w b}<2^{\circ} \mathrm{C}: \theta_{s, 2}=\theta_{s, 1}$ (Free cooling)}

B. Outside occupancy hours

a. $\theta_{i}>\theta_{i, s e t}: \quad \dot{V}=\dot{V}_{\max }: \theta_{s, 2}=\theta_{s, 1}$ (Free night cooling)

The air flow rate for hygienic ventilation rate $\dot{V}_{\text {min }}$ is calculated to meet the minimal ventilation requirements for a medium indoor air quality (IDA 2) [16]. Because IEC is often combined with free (night) cooling, a maximum ventilation capacity $\dot{V}_{\max }$ based on conventional cooling load calculations may lead to oversizing of the AHU. Therefore the maximum ventilation capacity can be determined by preliminary simulations.

During the following dynamic simulations the maximum ventilation rate $\dot{V}_{\max }$ is constant. Some additional heating of the supply air due to the supply fan was not taken into account. In figure 4 a typical temperature course is given for a summer day in the base case simulation (see 3.1).

\section{Parametric study}

In this part the interaction between the moisture balance and the thermal comfort is studied making use of a typical application in the Belgian climate.

\subsection{Modelling strategy}

As a case study, a generic room is analysed with a typical geometry of an office or a health care room. The room has a floor surface of $15 \mathrm{~m}^{2}$, a height of $2.8 \mathrm{~m}$ with a west facing façade containing a window a $3 \mathrm{~m}^{2}$. Only the west oriented wall is an external wall, all the other boundaries are adiabatic. No lowered ceiling or raised floor is used. Construction details and material properties are given in table 2 . The infiltration rate is 0.4 ach.

In the base case model the room is occupied during the office hours $(08-17 \mathrm{~h})$ by one person having a sensible heat production of $65 \mathrm{~W}$ and a moisture production of $0.07 \mathrm{~kg} / \mathrm{h}$ [17]. The same 
occupancy schedule was applied to all days in the simulation period. Internal gains due to one personal computer $(140 \mathrm{~W})$ and lights $\left(10 \mathrm{~W} / \mathrm{m}^{2}\right)$ are introduced. The total buffering capacity of the room was five times the capacity of the indoor air $(C=5)$, corresponding to $55 \mathrm{~m}^{2}$ plastered wall.

Simulations were run over an entire year using a 15-minute time step assuming that besides the IEC there was no other cooling device present. Solar gains are taken into account, no sunshading was present. An extreme warm weather data set, i.e. outdoor temperatures occurring once every 10year, for Uccle (Belgium) was created using Meteonorm. This program constructs the synthetic hourly weather data based on the climatological normals of 1961-1990 for a specific location [18].

During winter the indoor temperature setpoint is $20^{\circ} \mathrm{C}$. Based on the measured values of the IEC-effectiveness in section 2.2, a constant IEC-effectiveness equal to $85 \%$ was chosen in the model. The hygienic ventilation rate $\dot{V}_{\min }$ for one person is $36 \mathrm{~m}^{3} / \mathrm{h}(0.85 \mathrm{ach})$. In order to see the influence of the night cooling on the thermal comfort, the operation of the AHU with and without night cooling is compared for different $\dot{V}_{\max }$. Fig.5 compares the number of (weighted) temperature excess hours for an AHU with and without night cooling and shows that night cooling has an important influence on the thermal comfort realized in the building. Some first simulations showed that in the base case $\dot{V}_{\max }=3$ ach $\left(125 \mathrm{~m}^{3} / \mathrm{h}\right)$ yields to a good thermal comfort.

\subsection{Sensitivity analysis}

As the thermal performance of indirect evaporative cooling is influenced by the moisture balance of the room, a sensitivity analysis was performed by changing the parameters from the base case, which influence the indoor humidity (Eq.5): the maximum ventilation rate $\dot{V}_{\max }$, the indoor moisture production $\mathrm{M}_{\text {gain }}$ and the amount of moisture buffering capacity $\mathrm{C}$ which is available in 
the room.

The (weighted) temperature excess hours above $26^{\circ} \mathrm{C}$ were used as a performance indicator for thermal summer comfort [19]. The amount of time during which the operative temperature exceeds $26^{\circ} \mathrm{C}$ is multiplied with the temperature difference, in this way the extent of temperature excess is taken into account. Similar to the GTO-method [20] the maximum number of temperature excess hours during one year has been set to $100 \mathrm{~h}$ as a criterion for good thermal comfort. The number of temperature excess hours is calculated for the cases with and without IEC. In the latter free cooling with outdoor air is available if there is a cooling demand. The difference in temperature excess hours gives an indication of the thermal comfort improvement which can be realized using IEC. Furthermore the operation time of the IEC system during one year is derived. It gives an indication of the interaction between the operation of IEC and the indoor moisture balance.

\section{a. Maximum ventilation rate $V \max$}

First the maximum ventilation rate $\dot{V}_{\max }$ is varied. Fig.6 shows that the number of temperature excess hours decreases while increasing the maximum ventilation rate. With higher air flow rates, the operation time for the IEC increases. A high air flow rate causes more moisture to be removed from the room, which lowers the average indoor wet bulb temperature and thus increases the amount of time during which the control conditions for IEC are satisfied. Additionally the influence of free cooling increases due to the higher ventilation rate. Compared to the case with only free cooling, use of IEC is able to improve the comfort by about $25 \%$ if $\dot{V}_{\max }=60 \mathrm{~m}^{3} / \mathrm{h}$, and by about $95 \%$ if $\dot{V}_{\max }=250 \mathrm{~m}^{3} / \mathrm{h}$, based on the calculated temperature excess hours at both air flow rates. 


\section{b. Moisture production $\mathbf{M}_{\text {gain }}$}

Increasing the indoor moisture production $\mathrm{M}_{\text {gain }}$ has a large influence on the moisture balance of the room and therefore on the thermal performance of IEC. Depending on the number of people and their activity level, the indoor moisture gains in the room may increase. Apart from loads from occupants other gains such as bathing, washing etc. may be introduced. Fig.7 shows that with higher moisture production $\mathrm{M}_{\text {gain }}$ the number of temperature excess hours increases from $67 \mathrm{~h}$ at $0.07 \mathrm{~kg} / \mathrm{h}$ to $150 \mathrm{~h}$ at $1.5 \mathrm{~kg} / \mathrm{h}$, thus approaching the number of temperature excess hours in case the IEC is not in operation. Because of the high indoor humidity, a smaller temperature decrease can be realized in the supply air, which results in a larger number of temperature excess hours. If the indoor air humidity rises, the operation time decreases because the control conditions for IEC are less often fulfilled.

\section{c. Moisture buffering capacity C}

Moisture buffering is able to contribute to a more comfortable indoor climate since it dampens out humidity variations $[10,11]$. Different variations on the base case were simulated: if the walls and ceiling are vapour tight and no other hygroscopic materials are present the effective capacitance is equal to one. In the second variation the moisture buffer capacity from the base case is doubled.

Fig.8 demonstrates that the number of temperature excess hours decreases with a higher moisture buffering capacity. If the moisture buffering capacity increases, the indoor humidity peaks are damped out and the number of operation hours slightly increases because the control conditions for IEC are more often satisfied. Furthermore, the influence of the moisture buffering capacity on the temperature excess hours is smaller with a higher maximum ventilation rate. In this case less moisture is available to be absorbed and released by the hygroscopic surfaces in the room. 


\section{Conclusion}

An integrated simulation methodology of the building with its indirect evaporative cooling installation is necessary in order to take into account both heat and mass balance in building calculations. In this way it is possible to study the interaction between the thermal performance of an indirect evaporative cooling system and the moisture balance of a room.

The IEC-effectiveness was studied using measurements in an AHU containing an indirect evaporative cooling system. It was found that the thermal effectiveness is independent of the inlet conditions of the outdoor and return air.

Next, the interaction between the moisture balance and the thermal comfort was investigated for a typical application in the Belgian climate. The indoor comfort and operation time increase with high ventilation rates as they are favourable to help remove heat and moisture from the building. Furthermore the results showed that the thermal comfort decreases with increasing indoor moisture production indoor and thus higher wet bulb temperature. The amount of moisture buffering material determines how much the relative humidity variations are damped and therefore also directly affects the wet bulb temperature of the return air. The influence of the moisture buffering capacity is limited compared to the ventilation rate and the moisture production.

\section{Nomenclature}

C Effective capacitance [-]

$g \quad$ Solar admittance factor [-]

$M_{\text {gain }} \quad$ Indoor moisture production [kg/s]

$p_{v} \quad$ Vapour pressure $[\mathrm{Pa}]$

$R_{v} \quad$ Gas constant for water vapour $[\mathrm{J} / \mathrm{kgK}]$ 


$\begin{array}{ll}R H & \text { Relative humidity [\%] } \\ t & \text { Period of cyclic humidity variation [s] } \\ S & \text { Moisture buffering surface }\left[\mathrm{m}^{2}\right] \\ T & \text { Absolute temperature }[\mathrm{K}] \\ V & \text { Volume }\left[\mathrm{m}^{3}\right] \\ \dot{V} & \text { Ventilation rate }\left[\mathrm{m}^{3} / \mathrm{h}\right] \\ \varepsilon & \text { IEC-effectiveness }[\%] \\ \delta_{V} & \text { Vapour permeability }[\mathrm{kg} / \mathrm{Pams}] \\ \Delta & \text { Penetration depth }[\mathrm{m}] \\ \theta & \text { Temperature }\left[{ }^{\circ} \mathrm{C}\right] \\ \rho_{V} & \text { Vapour concentration }\left[\mathrm{kg} / \mathrm{m}^{3}\right] \\ \rho \xi & \text { Specific moisture capacity }\left[\mathrm{kg} / \mathrm{m}^{3}\right]\end{array}$

Subscripts

$\begin{array}{ll}\text { s } & \text { supply air } \\ r & \text { return air } \\ 1 & \text { air stream entering heat exchanger } \\ 2 & \text { air stream leaving heat exchanger } \\ \text { i } & \text { indoor } \\ \text { e } & \text { outdoor } \\ \text { wb } & \text { wet bulb temperature } \\ \text { sat } & \text { saturation } \\ \text { set } & \text { setpoint }\end{array}$

\section{Acknowledgements}

This $\mathrm{PhD}$ research is established with the financial support of the Flemish Institute for the 
Promotion and Innovation by Science and Technology in Flanders (IWT-SB/51283/Steeman).

\section{References}

[1] JRAIA - The Japan refrigeration and air conditioning industry association. Estimate of world demand for air conditioners 2000-2008. http://www.jraia.or.jp/frameset_english.html.

[2] Lazzarin M. Introduction of a simple diagram-based method for analyzing evaporative cooling. Applied Thermal Engineering 27 (2007) 2011-2025.

[3] ASHRAE. Chapter 51: Evaporative Cooling Applications. In: Fundamentals Handbook: HVAC Applications. American Society of Heating, Refrigerating and Air Conditioning Engineers. Atlanta, USA, 2003.

[4] Hens H. Annex 41. Whole Building Heat, Air and Moisture Response (MOIST-ENG). ECBCS News 38 (2003) 1-3. (www.ecbcs.org/annexes/annex41.htm)

[5] Simonson CJ, Salonvaara M, Ojanen T. The effects of structures on indoor humidity possibility to improve comfort and perceived air quality. Indoor Air 12 (2002) 243-251.

[6] Svennberg K, Hedegaard L, Rode C. Moisture buffer performance of a fully furnished room, ASHRAE Special Publications. Proceedings of Buildings IX Conference, 2004.

[7] Catalina T, Woloszyn M, Virgone J. Impact of moisture buffering on energy performance of cooling ceilings. Annex 41 meeting Lyon, 2006.

[8] Maalouf C, Wurtz E, Mendonça KC, Mora L. Parametric analysis of a desiccant cooling system: effect of hygrothermal interactions with building envelope - part1. Annex41 meeting, Trondheim, 2005.

[9] Woloszyn M, Kalamees T, Abadie MO, Steeman M, Kalagasidis AS. The effect of combining a relative-humidity-sensitive ventilation system with the moisture-buffering capacity of materials on indoor climate and energy efficiency of building. Building and Environment (2008) doi: 10.1016/j.buildenv.2008.04.017 (article in press). 
[10] Barbosa RM, Mendes N. Combined simulation of central HVAC systems with a whole-building hygrothermal model. Energy and Buildings (2007) doi 10.1016/j.enbuild.2007.02.022 (article in press).

[11] Osanyintola OF, Simonson CJ. Moisture buffering of hygroscopic building materials: experimental facilities and energy impact. Energy and Buildings 38 (2006) 1270-1282.

[12] SEL, TRANSSOLAR, CSTB, TESS. Trnsys 16: A TRanSient SYstem Simulation program. University of Wisconsin, Madison, USA, 2004.

[13] Janssens A, De Paepe M. Effect of moisture inertia models on the predicted indoor humidity in a room. Proceedings of the $26^{\text {th }}$ AIVC Conference, Brussels, 2005.

[14] Menerga Klimatechnologie. www.menerga.de

[15] Steeman M, Janssens A, De Paepe M. Performance evaluation of indirect evaporative cooling by means of measurements and dynamic simulations. Proceedings of the Sixth International Conference on Indoor Air Quality, Ventilation and Energy Conservation in Buildings (IAQVEC). Sendai, Japan, 2007, 1403-1410.

[16] CEN EN 13779. Ventilation for non-residential buildings - performance requirements for ventilation and room-conditioning systems. Brussels, Belgium, 2004.

[17] Harriman L, Brundrett G, Kittler R. Humidity control design guide for commercial and institutional buildings. American Society of Heating, Refrigerating and Air Conditioning Engineers, Artlanta, USA, 2001.

[18] Meteotest. Meteonorm: global meteorological database for engineers, planners and education, Version5.0. Bern, Switzerland, 2003.

[19] prEN 15251 Criteria for the indoor environment including thermal, indoor air quality, light and noise. CEN, Brussels, 2005.

[20] van der Linden K, Boerstra AC et. al. Thermal indoor climate building performance characterized by human comfort response. Energy and Buildings 34 (2002) 737-744. 
Figure 1: Scheme of the simulation methodology in TRNSYS

Figure 2: Operation of studied AHU with indirect evaporative cooling

Figure 3: Measured effectiveness in an AHU with indirect evaporative cooling (summer 2006)

Figure 4: Typical daily temperature course in the base case simulation

Figure 5: Comparison of (weighted) temperature excess hours above $26^{\circ} \mathrm{C}$ for an AHU with $(-\diamond-)$ and without (-๑-) night cooling

Figure 6: Influence of the maximum ventilation rate $\dot{V}_{\max }$ on the (weighted) temperature excess hours above $26^{\circ} \mathrm{C}$ with IEC $(-\diamond-)$, the (weighted) temperature excess hours above $26^{\circ} \mathrm{C}$ without IEC (-๑-) and the operation time (-o-). $\left(\mathrm{M}_{\text {gain }}=0.07 \mathrm{~kg} / \mathrm{h}, \mathrm{C}=5\right)$

Figure 7: Influence of moisture production $\mathrm{M}_{\text {gain }}$ on the (weighted) temperature excess hours above $26^{\circ} \mathrm{C}$ with IEC $(-\diamond-)$, the (weighted) temperature excess hours above $26^{\circ} \mathrm{C}$ without IEC (-口-) and the operation time (-०-). ( $\left.\dot{V}_{\max }=125 \mathrm{~m}^{3} / \mathrm{h}, \mathrm{C}=5\right)$

Figure 8: Influence of the effective capacitance C on the (weighted) temperature excess hours above $26^{\circ} \mathrm{C}$ with IEC if $\dot{V}_{\max }=125 \mathrm{~m}^{3} / \mathrm{h}(-\diamond-)$ and if $\dot{V}_{\max }=250 \mathrm{~m}^{3} / \mathrm{h}(-\mathrm{x}-)$; operation time if $\dot{V}_{\max }=125 \mathrm{~m}^{3} / \mathrm{h}(-\circ-)$ and if $\dot{V}_{\max }=250 \mathrm{~m}^{3} / \mathrm{h}(-\square-) .\left(\mathrm{M}_{\text {gain }}=0.07 \mathrm{~kg} / \mathrm{h}\right)$ 
Table 1: Measured values of IEC-effectiveness

Table 2: Construction details and material properties of the generic room 


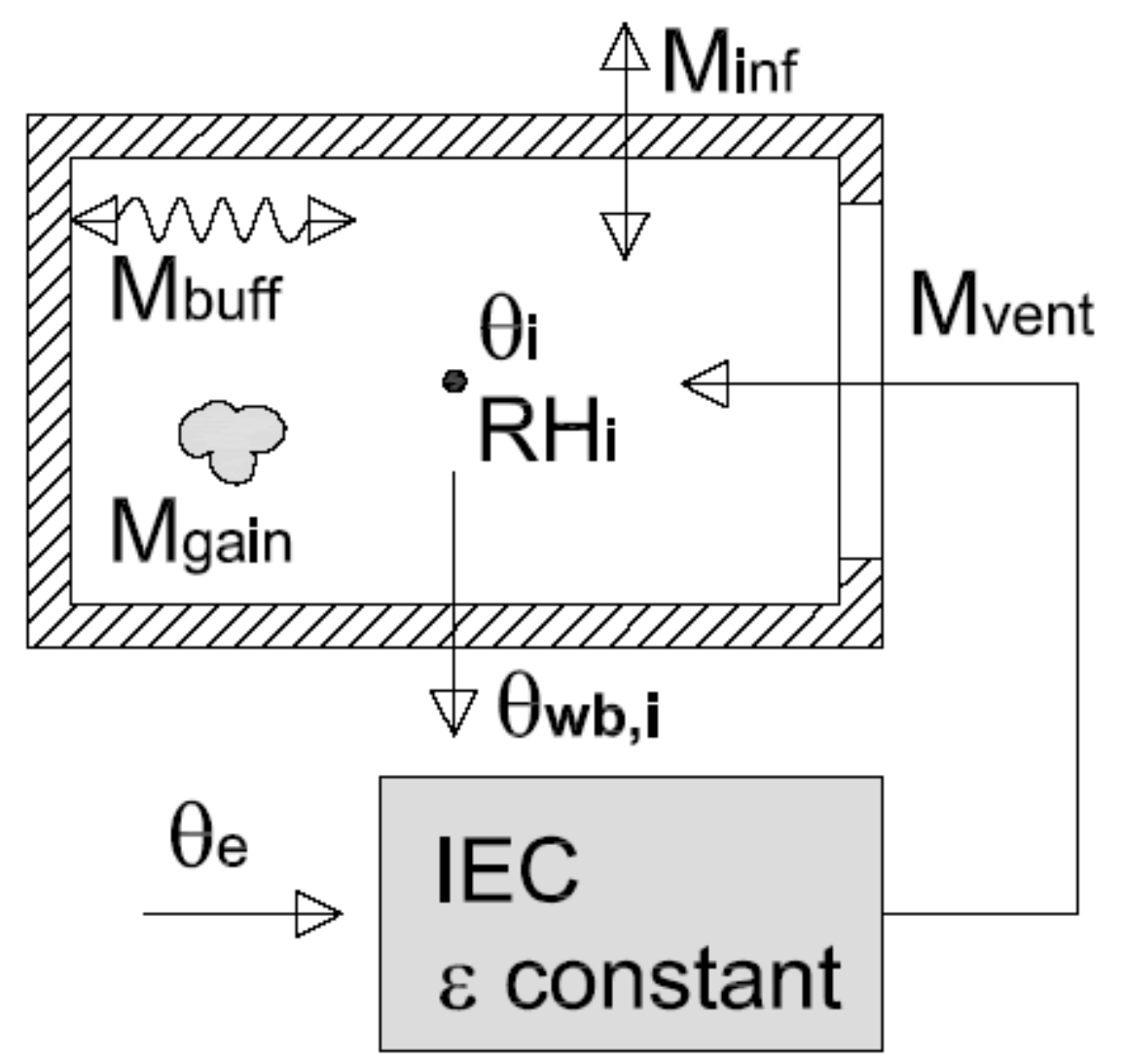

Fig.1 


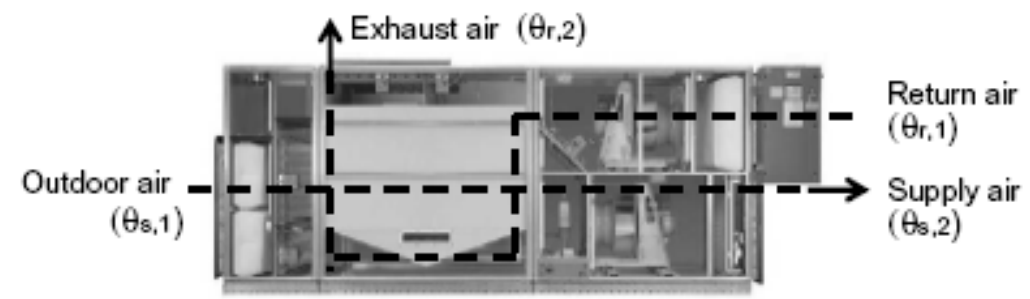

Fig.2 


\section{ACCEPTED MANUSCRIPT}

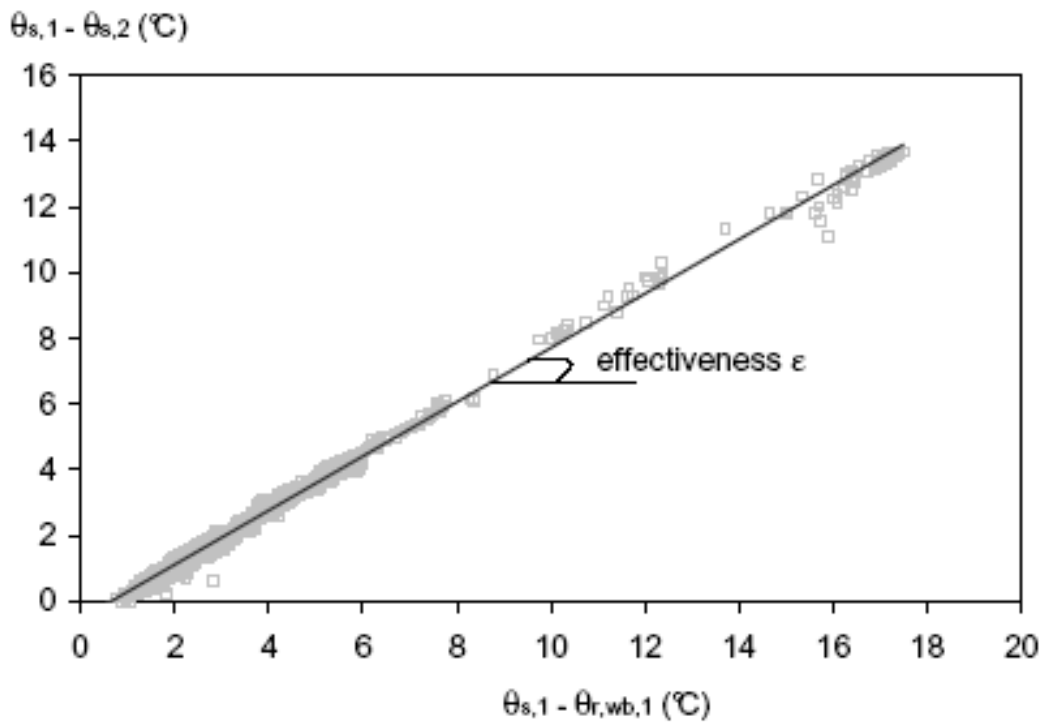

Fig.3 


\section{ACCEPTED MANUSCRIPT}

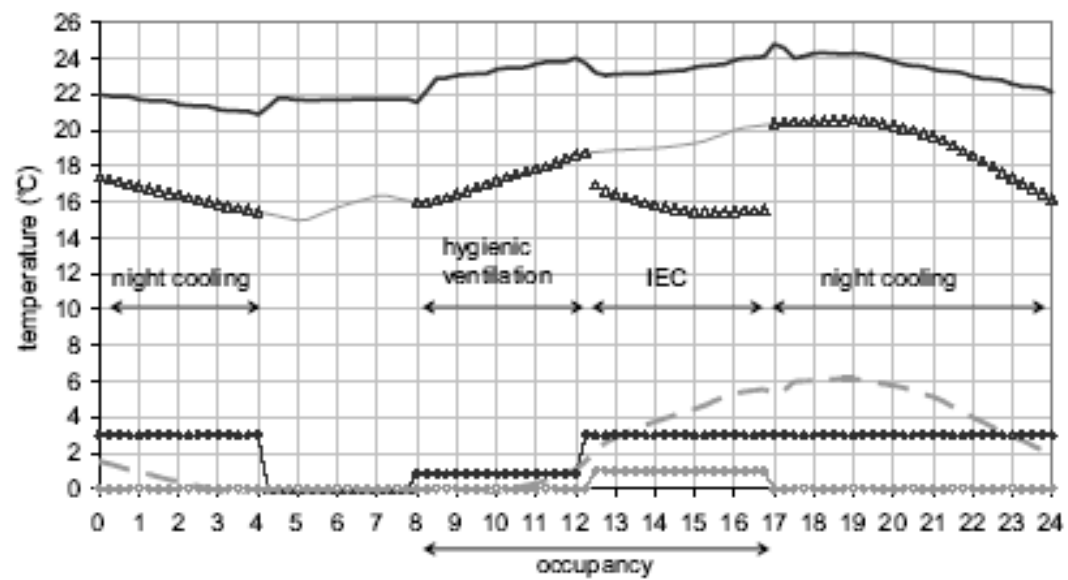

Fig.4

- Te - Ti a Tsupply $\rightarrow$ ach $\rightarrow$ IEC on $=$ Te-Ti,wb

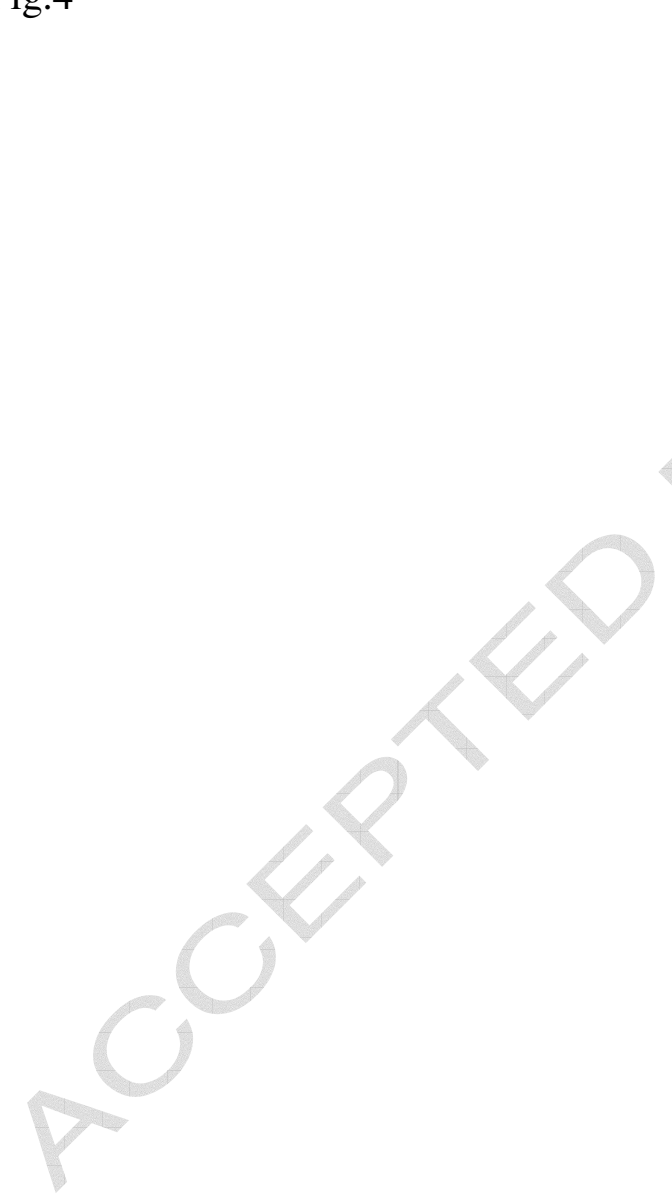




\section{ACCEPTED MANUSCRIPT}

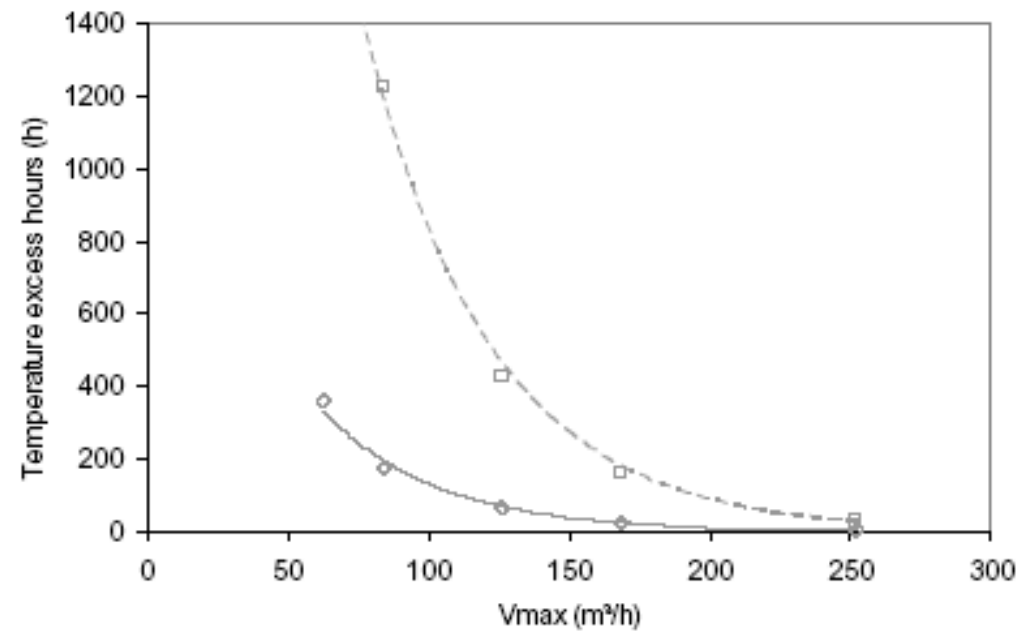

Fig.5 


\section{ACCEPTED MANUSCRIPT}

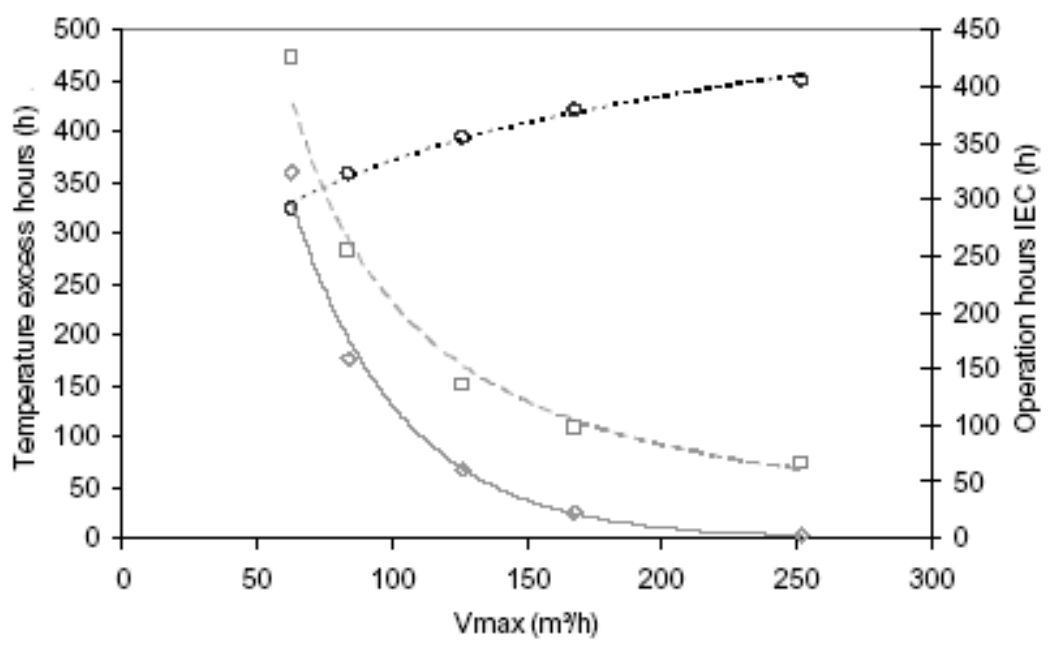

Fig.6 


\section{ACCEPTED MANUSCRIPT}

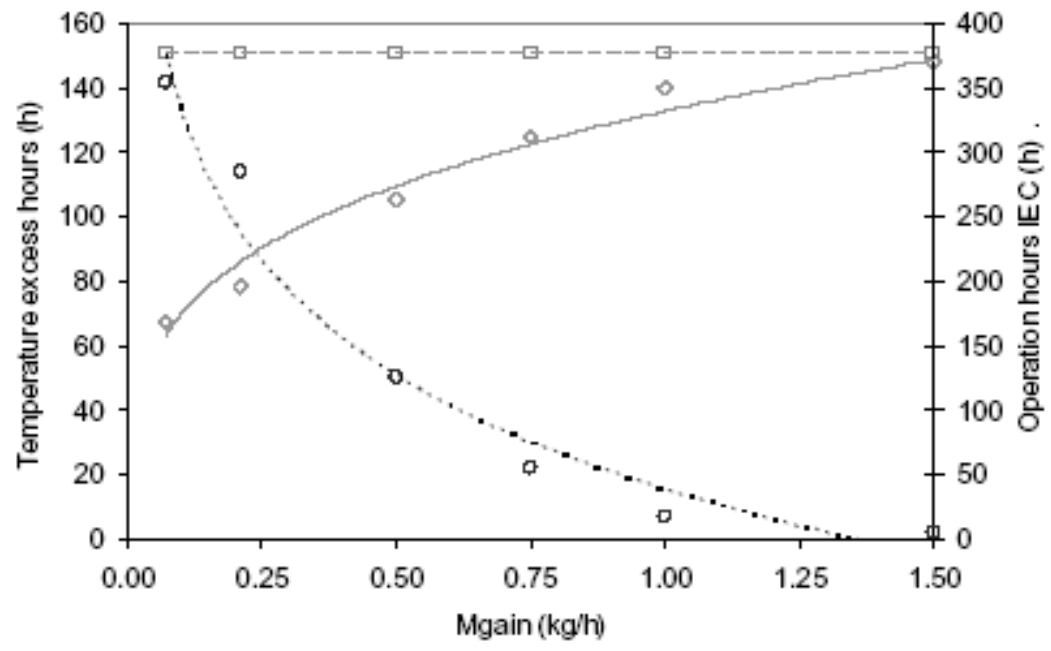

Fig.7 


\section{ACCEPTED MANUSCRIPT}

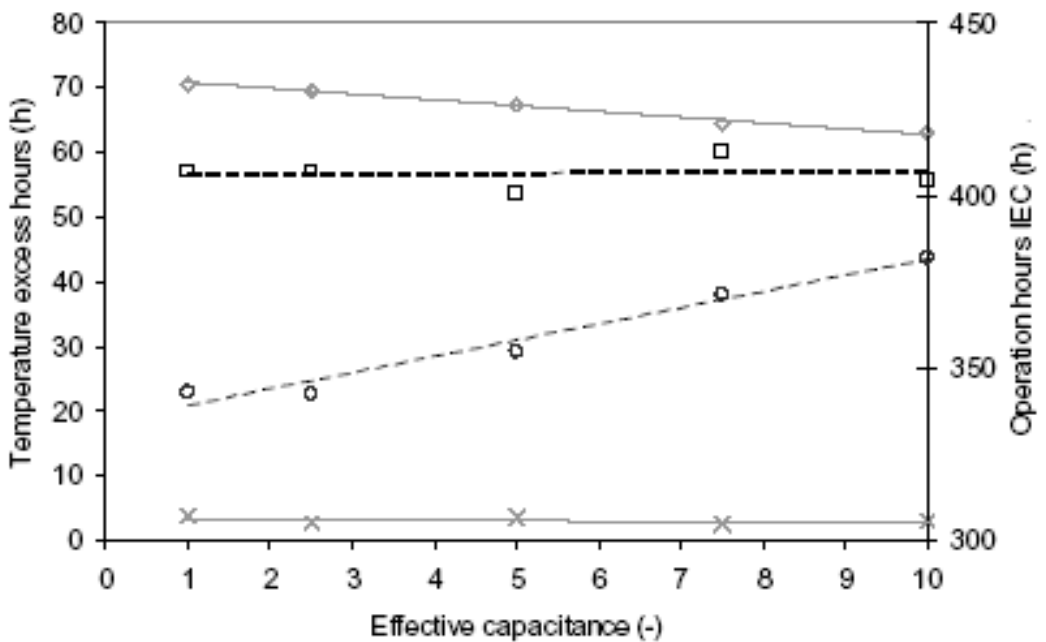

Fig.8 


\begin{tabular}{lllll}
\hline & $\mathrm{V}_{\max }\left(\mathrm{m}^{3} / \mathrm{h}\right)$ & $\begin{array}{l}\text { Heat exchanger } \\
\text { surface }\left(\mathrm{m}^{2}\right)\end{array}$ & $\varepsilon(\%)$ & $\mathrm{r}^{2}$ \\
\hline${ }^{\circ} 1$ & 2000 & 500 & 95 & 0.99 \\
${ }^{\circ} 2$ & 4300 & 500 & 80 & 0.96 \\
${ }^{\circ 3}$ & 6900 & 500 & 77 & 0.96 \\
${ }^{\circ} 4$ & 7100 & 380 & 82.5 & 0.99 \\
\hline
\end{tabular}




\begin{tabular}{|c|c|c|c|c|}
\hline Construction & Materials & $d(m)$ & $\lambda(\mathrm{W} / \mathrm{mK})$ & $\rho\left(\mathrm{kg} / \mathrm{m}^{3}\right)$ \\
\hline \multirow{5}{*}{$\begin{array}{l}\text { Exterior wall } \\
\text { (heavy) }\end{array}$} & Exterior bricks & 0.09 & 0.5 & 1250 \\
\hline & Air layer & 0.02 & $\mathrm{R}=0.14 \mathrm{~m}^{2} \mathrm{~K} / \mathrm{W}$ & 1 \\
\hline & EPS & 0.08 & 0.034 & 35 \\
\hline & Interior brick & 0.14 & 0.5 & 1250 \\
\hline & Plaster & 0.01 & 0.35 & 1200 \\
\hline \multirow{3}{*}{$\begin{array}{l}\text { Interior wall } \\
\text { (heavy) }\end{array}$} & Plaster & 0.01 & 0.35 & 1200 \\
\hline & Brick & 0.09 & 0.5 & 1250 \\
\hline & Plaster & 0.01 & 0.35 & 1200 \\
\hline \multirow{3}{*}{ Floor } & Finishing carpet & 0.005 & 0.061 & 200 \\
\hline & Light concrete & 0.07 & 0.23 & 750 \\
\hline & (Heavy) concrete & 0.10 & 1.7 & 2200 \\
\hline \multirow{2}{*}{ Ceiling } & (Heavy) concrete & 0.10 & 1.7 & 2200 \\
\hline & Plaster & 0.01 & 0.35 & 1200 \\
\hline \multirow{2}{*}{ Window } & & $\mathrm{U}_{\text {glass }}\left(\mathrm{W} / \mathrm{m}^{2} \mathrm{~K}\right)$ & $g(-)$ & $U_{\text {frame }}\left(\mathrm{W} / \mathrm{m}^{2} \mathrm{~K}\right)$ \\
\hline & 6/16/6 Argon gold & 1.3 & 0.212 & 2.27 \\
\hline
\end{tabular}

